\title{
RANCANG BANGUN SPECTROSCOPY OPTIK PORTABEL BERBASIS ARDUINO MICRO
}

\author{
I Gede Yogi Astawan, Yoga Divayana, Pratolo Rahardjo* \\ "Program Studi Teknik Elektro, Fakultas Teknik, Universitas Udayana \\ `Email: yogiastawan@student.unud.ac.id, yoga@unud.ac.id, pratolo@unud.ac.id
}

\begin{abstract}
ABSTRAK
Penelitian ini dilakukan untuk membangun spectroscopy optik portabel dengan aplikasi Android dan Desktop. Spectroscopy optik portable terdiri dari Arduino Micro, Nextion Liquid Crystal Display (LCD), 2 buah Light Emitting Diode (LED), motor servo, kisi difraksi (600 garis $/ \mathrm{mm}$ ), 2 buah photodiode, Bluetooth HC-05, dan SD Card Reader Writer. Aplikasi Android dan desktop direalisasikan menggunakan Qt IDE. Pengujian spectroscopy dilakukan dengan menggunakan polimer warna merah, hijau, dan biru. Hasil pengukuran sampel polimer menunjukkan bahwa spektrum dengan rentang panjang gelombang yang sama dengan warna sampel akan diteruskan, sedangkan panjang gelombang yang lain akan diserap. Sehingga alat telah mampu mengukur penyerapan spektrum sampel. Pada pengujian menyimpan hasil pengukuran pada SD card menghasilkan file dengan ukuran sekitar $2 \mathrm{kB}$. Alat menggunakan baterai berkapasitas 3000 mAh dan dapat aktif secara berkelanjutan selama 3 jam 31 menit. Pengujian komunikasi aplikasi Android dan desktop dengan spectroscopy dilakukan menggunakan bluetooth dan kabel Universal Serial Bus (USB). Hasil dari pengujian aplikasi adalah dapat mengirimkan dan menerima data dari spectroscopy.
\end{abstract}

Kata Kunci: Android, Aplikasi Desktop, Penyerapan Spektrum, Spectroscopy Vis

\section{ABSTRACT}

This research is conducted to build portable spectroscopy optic with Android and desktop applications. Portable spectroscopy optic consists of Arduino Micro, Nextion Liquid Crystal Display (LCD), 2 pieces Light Emitting Diodes (LED), servo motor, diffraction grating (600 lines/mm), 2 pieces photodiodes, Bluetooth HC-05, and SD Card Reader Writer. Android and desktop applications realized by using Qt IDE. Spectroscopy testing is done using polymers with color red, green, and blue. The result of polymers sample testing shows that the spectrum with same wavelength range as the sample color will be passed, while other wavelengths will be absorbed. The device has been able to measure absorption of sample. On testing restore the test results to the SD card produces file with size about $2 \mathrm{kB}$. Device uses battery with capacity $3000 \mathrm{mAh}$ and can be actively sustainable during 3 hours 31 minutes. Testing of communication Android and desktop applications with spectroscopy is done using bluetooth and Universal Serial Bus (USB) cable. The result of application testing are already able to send and receive data from spectroscopy.

\section{Keywords: Android, Desktop Application, Spectrum Absroption, Spectroscopy Vis}

\section{Pendahuluan}

Spectroscopy merupakan ilmu yang mempelajari interaksi antara cahaya dengan materi untuk menganalisis atau menentukan zat organik dan anorganik baik secara kualitatif maupun kuantitatif [1]. Alat yang digunakan dalam pengukuran spectroscopy disebut dengan spektrometer.

Penelitian mengenai bidang spectroscopy portabel masih sedang di kembangkan. Anuradha Kar, dk (2015) mengembangkan spectroscopy portabel untuk memonitor keadaan lingkungan [2]. Y Zhang, dkk (2009) mengembangkan spectrsocopy portabel untuk mengukur tissue oxigenation [3]. Kyung-Jin Baik, dkk (2017) melakukan penelitian spectroscopy portabel untuk mengidentifikasi jenis tablet obat farmasi [4].

Tujuan penelitian ini adalah melakukan perancangan spectrsocopy optik portabel dengan aplikasi Android dan desktop. spectroscopy dirancang 
menggunakan Arduino Micro sebagai pengontrol utama, LED Putih sebagai sumber cahaya dengan panjang gelombang $\sim 400 \mathrm{~nm}$ sampai dengan $\sim 700 \mathrm{~nm}$, bluetooth untuk komunikasi antara spectroscopy optik portabel dengan aplikasi Android, dan Modul SD Card Reader Writer untuk menyimpan hasil pengukuran ke SD card.

Perancangan aplikasi Android dan desktop dilakukan dengan menggunakan Qt Integrated Development Environment (IDE). Komunikasi antara aplikasi Android dengan spectroscopy dilakukan dengan menggunakan bluetooth, sedangkan dalam aplikasi desktop dilakukan dengan menggunakan kabel USB.

\section{Kajian Pustaka}

\subsection{Spectrosscopy Optik}

Spectroscopy optik menggunakan cahaya tampak sebagai sumber cahayanya. Spectroscopy digunakan untuk mengukur konsentrasi suatu zat pada suatu sampel. Prinsip kerjanya berdasarkan pada penyerapan spektrum cahaya oleh sampel. Besarnya penyerapan spektrum cahaya dirumuskan dengan (1) [5].

$$
A=\log \frac{I_{0}}{I_{t}}
$$

Pada persamaan (1), A merupakan besarnya penyerapan spektrum cahaya oleh sampel. $I_{t}$ menyatakan besarnya intensitas cahaya yang melewati sampel, sedangkan $I_{0}$ merupakan intensitas cahaya sebelum melewati sampel atau intensitas cahaya yang melewati referensi [6].

\subsection{Nextion Liquid Crystal Display (LCD)}

Nextion LCD merupakan Human Machine Interface yang dilengkapi dengan capacitive touchscreen. Nextion LCD berfungsi untuk menampilkan grafik penyerapan spektrum sampel. Penelitian ini menggunakan LCD dengan ukuran 3,5 inchi.

\subsection{Arduino Micro}

Arduino micro merupakan board mikrokontroler yang berfungsi sebagai pengontrol sistem spectrsocopy optik portabel. Arduino Micro menggunakan Atmega32u4 sebagai mikrokontrolernya yang disertai dengan fitur USB 2.0 [7].

\subsection{Photodiode}

Photodiode digunakan sebagai sensor cahaya (detektor) untuk mendeteksi intensitas spektrum cahaya yang melewati sampel dan referensi. Sensor photodiode dihubungkan ke pin $A D C$ Arduino Micro, sehingga didapatkan data digital intensitas spektrum cahaya dari sampel dan referensi.

\subsection{Motor Servo}

Pada penelitian ini motor servo digunakan untuk menggerakkan kisi difraksi, sehingga cahaya monokrom hasil difraksi mengenai sampel secara bergantian dari panjang gelombang $\sim 400 \quad \mathrm{~nm}$ sampai dengan $\sim 700 \mathrm{~nm}$.

\subsection{Bluetooth HC-05}

Pada penelitian ini modul Bluetooth HC05 digunakan untuk mengirim data hasil pengukuran penyerapan spektrum sampel ke aplikasi Android.

\subsection{Modul SD Card Reader Writer}

Micro SD Card Reader Writer berfungsi untuk melakukan penyimpanan data hasil pengukuran penyerapan spektrum ke micro SD card. Data hasil disimpan dalam bentuk berkas dengan format JSON yang dapat dibuka pada aplikasi desktop dan android.

\section{Metodologi Penelitian \\ 3.1 Perancangan Hardware}

Diagram blok perangkat keras spectroscopy optik portabel ditunjukkan pada Gambar 1. Power supply menggunakan 2 buah baterai Li-Ion 3,7 V 3000 mAh yang disusun secara seri. Tombol start berfungsi untuk memulai pengukuran penyerapan spektrum dari sampel. Tombol stop berfungsi untuk menghentikan proses pengukuran, dan tombol reset digunakan untuk mereset sistem.

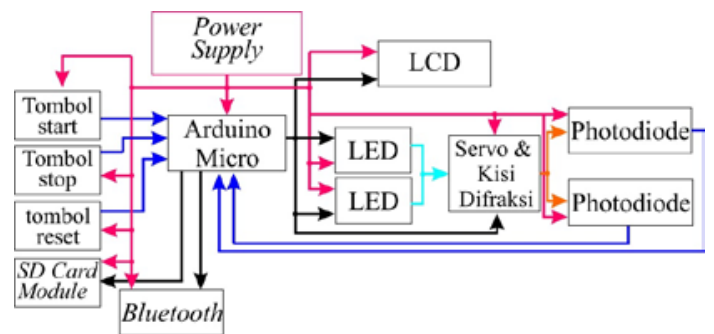

Gambar 1 Diagram Blok Hardware

Garis merah menandakan catu daya sistem, garis berwarna cyan menunjukkan cahaya polikromatik dari LED yang akan 
didifraksi. Garis yang berwarna jingga menunjukkan cahaya monokromatik, yang akan diteruskan ke sampel dan referensi, dan kemudian dideteksi oleh sensor photodiode. Garis yang berwarna biru dan hitam menunjukkan masukan dan keluaran Arduino Micro. Susunan hardware spectroscopy ditunjukkan pada Gambar 2.

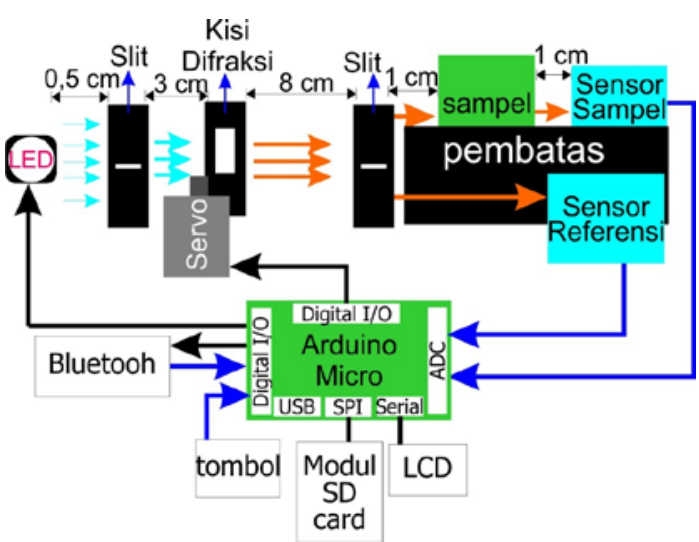

Gambar 2 Susunan Komponen Spectroscopy Optik Portabel

Ketika melakukan pengukuran Arduino Micro akan mengaktifkan LED yang akan menghasilkan cahaya polikromatik. Cahaya polikromatik akan diteruskan ke slit untuk memfokuskan cahaya, yang selanjutnya akan melewati kisi difraksi, sehingga dihasilkan cahaya monokromatik dari rentang $\sim 400 \mathrm{~nm}$ sampai dengan $\sim 700 \mathrm{~nm}$. Selanjutnya Arduino Micro akan menggerakkan motor servo, sehingga kisi difraksi juga ikut bergerak yang akan menyebabkan cahaya monokromatik melewati slit secara bergantian dan menuju sampel serta referensi. Intensitas cahaya monokromatik yang melewati sampel dan referensi akan dideteksi menggunakan sensor photodiode, dan dari hasil pengukuran intensitas dilakukan perhitungan penyerapan spektrum dengan menggunakan persamaan (1). Hasil pengukuran penyerapan spektrum ditampilkan pada LCD dalam bentuk grafik, dimana sumbu $X$ menunjukkan panjang gelombang dan sumbu $Y$ menunjukkan tingkat penyerapan.

Pengujian spectroscopy dilakukan dengan menggunakan polimer dengan warna merah, hijau, dan biru. Hasil pengujian dengan polimer dianalisis, yang dimana spektrum cahaya yang sesuai dengan warna polimer tidak akan (sedikit) mengalami penyerapan.
Pada perancangan spectroscopy juga dilakukan pengujian menyimpan hasil pengukuran ke dalam SD card dan pengujian penggunaan energi baterai. Pengujian menyimpan hasil pengukuran dilakukan dengan menyimpan hasil pengukuran masing-masing polimer dengan nama file sesuai dengan warna polimer. Pengujian penggunaan energi baterai dilakukan dengan cara mengaktifkan spectroscopy secara berkelanjutan hingga batas maksimum penggunaan yaitu $20 \%$ dari kapasitas maksimum (2) dan batas tegangan minimum yang dicapai baterai (3) [8].

$$
\begin{gathered}
\text { Amaks }=\text { Cbatt }-20 \% \\
\text { Vmin }=(\text { Vmaks }-20 \%) \times n \text { sel }
\end{gathered}
$$

\subsection{Perancangan Software}

Perancangan software meliputi perancangan Aplikasi Android dan aplikasi desktop. Perancangan aplikasi bertujuan untuk memudahkan analisis hasil grafik pengukuran penyerapan spektrum. Diagram alir aplikasi ditunjukkan pada Gambar 3.

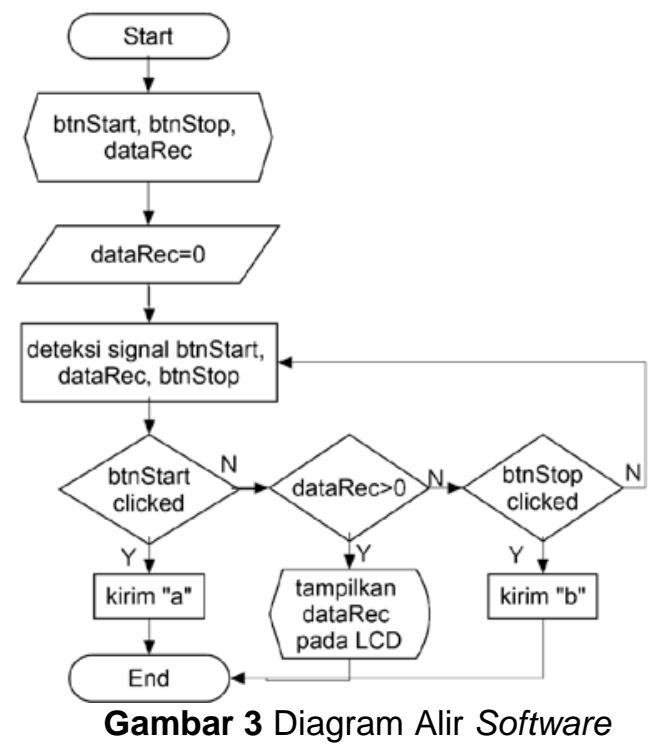

Pada aplikasi dilakukan pengujian komunikasi antara spectroscopy dengan aplikasi. Pengujian dilakukan dengan mengontrol spectroscopy melalui aplikasi untuk memulai pengukuran terhadap sampel dan mengirimkan data hasil pengukuran dari sepctroscopy ke aplikasi.
4. Hasil dan Pembahasan
4.1 Hasil Realisasi Spectroscopy Optik Portabel


Realisasi spectroscopy optik portabel ditunjukkan pada Gambar 4. Spectroscopy memiliki ukuran panjang $20 \mathrm{~cm}$, lebar $15 \mathrm{~cm}$ dan tinggi $15 \mathrm{~cm}$.

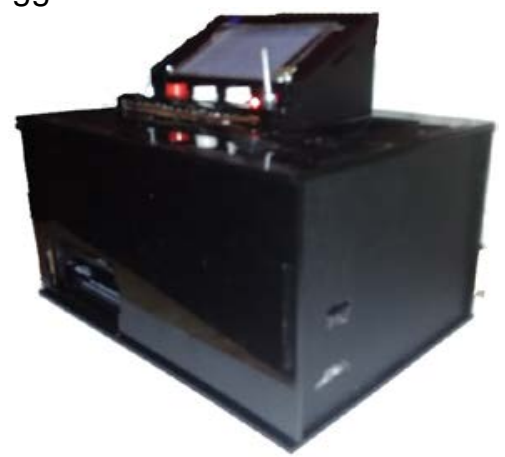

Gambar 4 Realisasi Spectroscopy Optik Portabel

Dari realisasi spectroscopy didapatkan untuk mengarahkan cahaya monokromatik dari $\sim 400 \mathrm{~nm}$ sampai dengan $\sim 700 \mathrm{~nm}$ dilakukan dengan menggerakkan motor servo dari lebar pulsa 940 mikrosekon sampai 1140 mikrosekon. Untuk menentukan panjang gelombang cahaya monokromatik yang diarahkan ke sampel dan referensi digunakan persamaan (4).

$$
\begin{gathered}
\frac{1140-940}{\text { pulsewidth }-940}=\frac{700-400}{\text { wavelength }-400} \\
\text { wavelength }=\frac{4220-(3 \times \text { pulsewidth })}{2}
\end{gathered}
$$

\subsubsection{Pengujian Spectroscopy Optik Portabel dengan Polimer}

Pengujian spectroscopy optik portabel dengan menggunakan polimer dilakukan dengan memotong polimer warna merah, hijau, dan biru dengan ukuran lebar $2 \mathrm{~cm}$ dan panjang $4 \mathrm{~cm}$ sebagai sampel, yang ditunjukkan pada Gambar 5. Masing-masing sampel polimer kemudian dimasukkan ke dalam tempat sampel secara bergantian, yang selanjutnya dilakukan pengukuran penyerapan spektrum. Hasil penyerapan spektrum akan ditampilkan berupa grafik pada LCD.
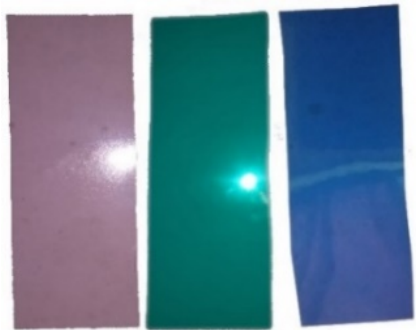

Gambar 5 Polimer Sebagai Sampel
Hasil pengukuran penyerapan spektrum sampel polimer warna merah, hijau, dan biru masing-masing ditunjukkan pada Gambar 6, Gambar 7, dan Gambar 8. Masing-masing grafik hasil pengukuran dianalisis untuk menentukan rentang penyerapan spektrum cahaya.

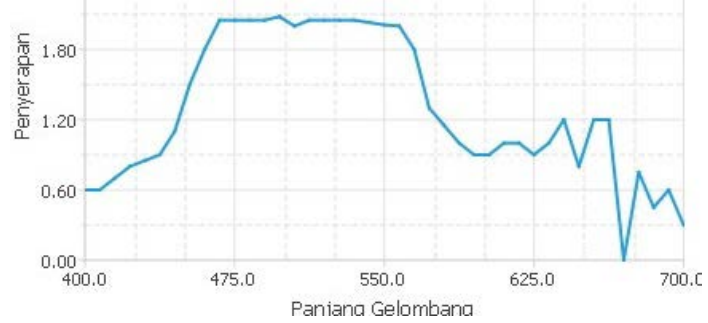

Gambar 6 Hasil Penyerapan Spektrum Polimer Warna Merah

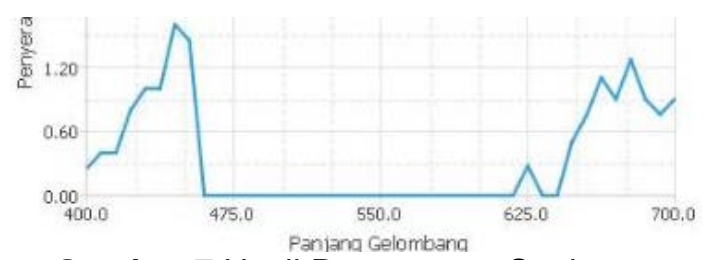

Gambar 7 Hasil Penyerapan Spektrum Polimer Warna Hijau

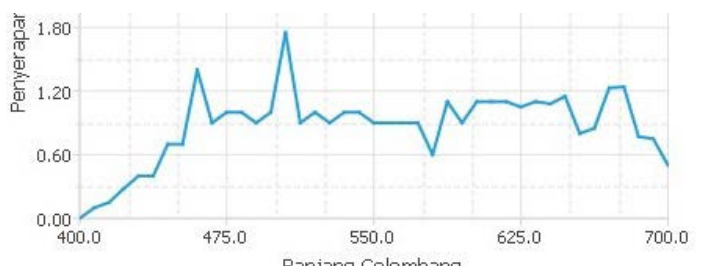

Gambar 8 Hasil Penyerapan Spektrum Polimer Warna Biru

Dari Gambar 6 didapatkan bahwa pada rentang panjang gelombang $\sim 660 \mathrm{~nm}$ sampai $\sim 700 \mathrm{~nm}$ yang merupakan spektrum warna merah, sebagian besar cahaya diteruskan sehingga tingkat penyerapan spektrum menjadi kecil mendekati 0,5 hingga 0 . Sedangkan spektrum pada rentang $\sim 400 \mathrm{~nm}$ sampai dengan $\sim 660 \mathrm{~nm}$ mengalami penyerapan. Analisis grafik penyerapan spektrum polimer warna merah ditunjukkan pada Gambar 9. 


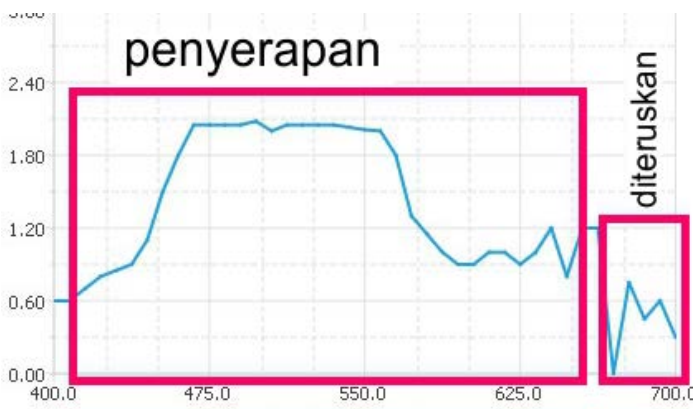

Gambar 9 Analisis Penyerapan Spektrum Polimer Warna Merah

Pada Gambar 7 menunjukkan bahwa pada rentang panjang gelombang $\sim 460 \mathrm{~nm}$ sampai $\sim 630 \mathrm{~nm}$ (warna hijau-kuning) spektrum cahaya diteruskan yang menyebabkan tingkat penyerapan spektrum menjadi sangat kecil mendekati 0 , sedangkan pada rentang panjang gelombang $\sim 400 \mathrm{~nm}$ sampai dengan $\sim 460$ $\mathrm{nm}$ dan $\sim 430 \mathrm{~nm}$ sampai $\sim 700 \quad \mathrm{~nm}$ mengalami penyerapan. Analisis dari grafik penyerapan spektrum polimer warna hijau ditunjukkan pada Gambar 10.

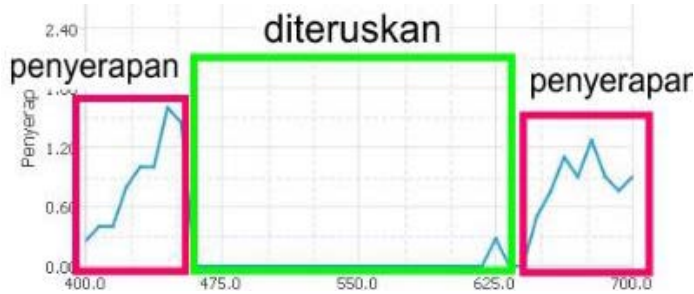

Gambar 10 Analisis Penyerapan Spektrum Polimer Warna Hijau

Gambar 8 menunjukkan bahwa spektrum cahaya pada rentang panjang gelombang $\sim 400 \mathrm{~nm}$ sampai $\sim 450 \mathrm{~nm}$ (warna biru-ungu) sebagian besar spektrum cahaya diteruskan atau sedikit mengalami penyerapan, sedangkan spektrum cahaya pada rentang $\sim 450 \mathrm{~nm}$ sampai $\sim 700 \mathrm{~nm}$ mengalami penyerapan. Analisis terhadap grafik penyerapan spektrum warna biru ditunjukkan pada Gambar 11.

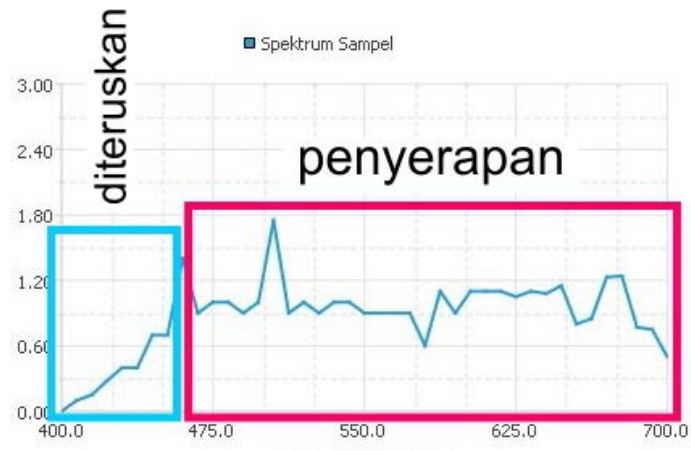

Gambar 11 Analisis Penyerapan Spektrum Polimer Warna Biru

\subsubsection{Pengujian Menyimpan Hasil Pengukuran Ke Dalam SD Card}

Pengujian menyimpan hasil pengukuran ke dalam SD card dilakukan dengan terlebih dahulu memasukkan SD Card ke dalam slot Modul SD Card Reader Wrtiter. Selanjutnya hasil dari setiap pengukuran polimer disimpan dengan cara mengelik menu, lalu pilih save, kemudian isikan nama file sesuai dengan warna polimer yang ditunjukkan pada Gambar 12, kemudian tekan tombol save.

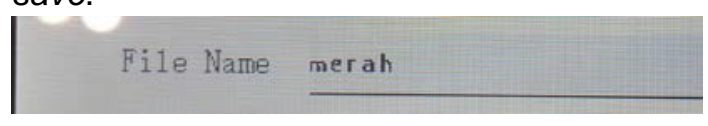

Gambar 12 Menyimpan Hasil Pengukuran

Setelah hasil pengukuran selesai disimpan, selanjutnya dikeluarkan dari slot Modul SD Card Reader Writer, kemudian dimasukkan ke dalam Laptop menggunakan SD adapter untuk mengecek file yang telah dibuat yang ditunjukkan pada Gambar 13. File yang dibuat memiliki ukuran hingga 2 $\mathrm{kB}$.

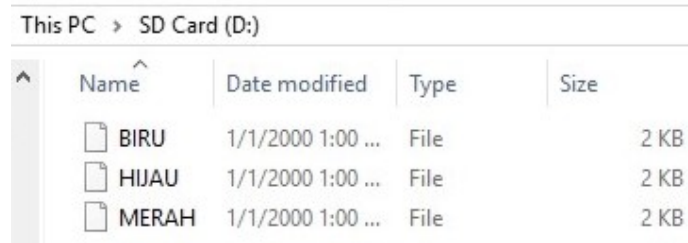

Gambar 13 Berkas File yang Dibuat

\subsubsection{Pengujian Penggunaan Daya Baterai Spectroscopy Optik Portabel}

Penelitian ini menggunakan 2 buah baterai Li-Ion 3,7 V 3000 mAh yang disusun secara seri. Berdasarkan persamaan (3) didapatkan batas penggunaan tegangan 
baterai minimum yang diperbolehkan sebesar 6,72 V. Pengujian dilakukan dengan mengaktifkan spectroscopy secara berkelanjutan hingga tegangan baterai mencapai $6,72 \mathrm{~V}$, dan digunakan timer untuk mengukur waktu yang diperlukan. Hasil pengujian ditunjukkan pada grafik Gambar 14.

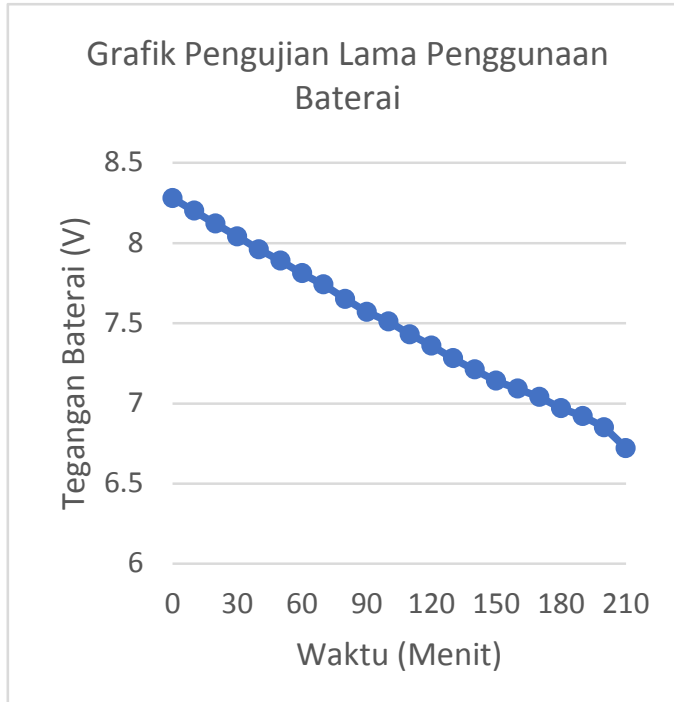

Gambar 14 Grafik Pengujian Penggunaan Daya Baterai

Berdasarkan grafik Gambar 14 dapat diketahui spectroscopy dapat bekerja hingga 211 menit (3 jam 31 menit).

\subsection{Hasil Realisasi Aplikasi Android dan Desktop}

Pengujian aplikasi Android dilakukan dengan terlebih dahulu menghubungkan spectroscopy dengan aplikasi Android menggunakan bluetooth. Kemudian sampel dimasukkan ke spectroscopy. Selanjutnya tombol start pada aplikasi android ditekan. Hasil dari pengujian aplikasi Android ditunjukkan pada Gambar 15.

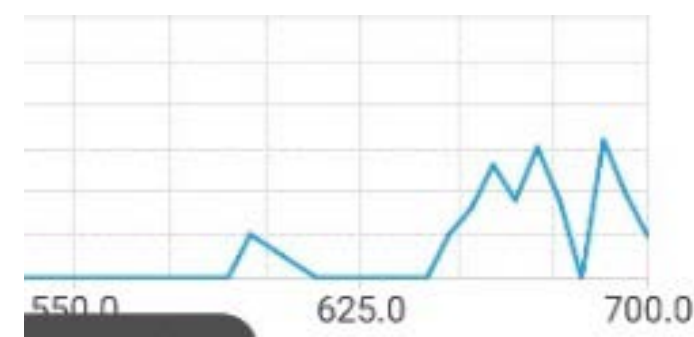

Gambar 15 Pengujian Aplikasi Android

Dari Gambar 15 dapat diketahui spectroscopy berhasil menerima data yang dikirim dari aplikasi Android berupa perintah untuk melakukan pengukuran. Aplikasi Android juga telah berhasil menerima data hasil pengukuran yang dikirimkan dari spectroscopy.

Dalam pengujian komunikasi data aplikasi desktop dilakukan dengan cara menghubungkan spectroscopy dengan aplikasi desktop menggunakan kabel micro USB tipe B. Sampel dimasukkan ke spectroscopy. Selanjutnya tombol start pada aplikasi android desktop ditekan. Hasil dari pengujian aplikasi desktop ditunjukkan pada Gambar 16.

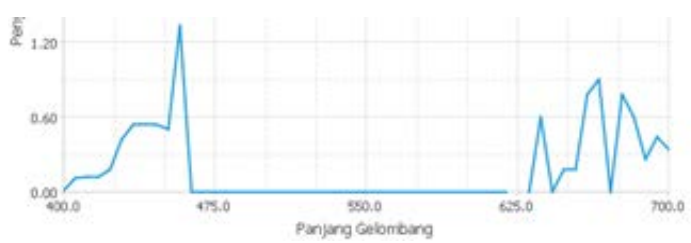

Gambar 16 Pengujian Aplikasi Desktop

Pada Gambar 16 dapat diketahui spectroscopy berhasil menerima data yang dikirimkan dari aplikasi desktop yang berupa perintah untuk memulai pengukuran penyerapan spektrum sampel. Selain itu spectroscopy juga telah berhasil mengirimkan data hasil pengukuran yang kemudian diterima aplikasi desktop.

\section{Kesimpulan}

Dari penelitian yang telah dilakukan dapat disimpulkan bahwa:

1. Spectroscopy telah mampu mengukur penyerapan spektrum dari polimer, spektrum cahaya dengan rentang panjang gelombang yang sama dengan warna sampel diteruskan, sedangkan rentang panjang gelombang yang lain diserap.

2. Spectroscopy telah berhasil menyimpan file hasil pengukuran ke dalam SD card.

3. Pada keadaan aktif secara terus menerus spectroscopy dapat aktif selama 3 jam 31 menit dengan menggunakan 2 buah baterai Li-Ion 3,7 V 3000 mAh.

4. Aplikasi Android dan desktop telah berhasil berkomunikasi dengan spectroscopy untuk menerima dan mengirimkan data.

\section{Daftar Pustaka}

[1] Etty Triyati. Spektrofotometer UltraViolet dan Sinar Tampak Serta Aplikasinya dalam Oseanologi. Oseana. 1985. 10(1), 39-47. 
[2] Anuradha Kar, Asim Kar, A novel design of a portable double beam-intime spectrometric sensor platform with cloud connectivity for environmental monitoring applications, IEEE. 2015,1-6.

[3] Y. Zhang, J. W. Sun, F.Scopesi, dkk, Design of a Portable Near Infra-Red Spectroscopy System for Tissue Oxygenation Measurement. IEEE. 2009, 1-4.

[4] Kyung-jin Baik, Jae Hyung L., Youngsik K., dkk, Pharmaceutical Tablet Classification Using a Portable Spectrometer with Combinations of Visible and Near-Infrared Spectra. IEEE. 2017,1011-1014.

[5] D.A. SKOOG, D.M. WEST. Principles of instrumental analysis. New York: Holt, Rinehart and Winston, Inc., 1971.

[6] Tati Suharti. Dasar-Dasar Spektrofotometri Uv-Vis dan Spektrometri Massa Untuk Penentuan Struktur Senyawa Organik. Bandar Lampung: AURA, 2017:11-13.

[7] Atmel Corporation. ATmega16U4ATmega32U4. 2010. [online]. Available: https://cdn.sparkfun.com/datasheets/De v/Arduino/Boards/ATMega32U4.pdf [accessed 8 November 2018].

[8] Tattu. Important Safety Instructions And Warnings, Dublin: Tattu, 2018. 